\title{
Legal Protection for The Indigenous Law Communities and Their Traditional Rights Based on the Verdict of the Constitutional Court
}

\author{
Putera Astomo*, Asrullah ** \\ DOI: https://doi.org/10.22304/pjih.v6n1.a5
}

Submitted: Jan 26, 2019 | Accepted: April 23, 2019

\begin{abstract}
This study covers the problems related to the regulation of Adat (Indigenous) law communities. First, the Law Number 41 of 1999 on Forestry categorizes indigenous forests as State Forest. Therefore, the state has the authority to stipulate indigenous forests as long as the relevant Indigenous Law Communities are still existed and recognized. Second, the Law Number 27 of 2007 on Management of Coastal Areas and Small Islands provides opportunities for owners of large capital through Coastal Water Concession Rights (HP-3), but the substance does not provide space for coastal communities especially fishermen carrying out economic activities in coastal areas. Due to limited capital and technology, coastal communities are not able to compete with large capital owners hence the poverty level of fishermen keeps increasing. Finally, the Law Number 41 of 1999 on Forestry and the Law Number 27 of 2007 on Management of Small Coastal Areas and Islands tested materially to the Constitutional Court. The research method used in this study is normative legal research. The results of the research are forms of legal protection against the existence of indigenous law communities and their traditional rights, which include protection of their indigenous rights over the status and management of indigenous forests and their protection over the management of coastal areas and small islands.
\end{abstract}

Keywords: indigenous law communities, legal protection, verdict.

\section{Perlindungan Hukum terhadap Hak Tradisional Masyarakat Adat berdasarkan Putusan Mahkamah Konstitusi}

\begin{abstract}
Abstrak
Masalah-masalah yang berhubungan dengan pengaturan kesatuan masyarakat hukum adat. Pertama, status Hutan Adat termasuk kategori Hutan Negara sebagaimana diatur dalam UU No. 41 Tahun 1999 tentang Kehutanan di mana negara berwenang menetapkan hutan adat sepanjang menurut kenyataannya masyarakat hukum adat yang bersangkutan masih ada dan diakui keberadaannya. Kedua, UU No. 27 Tahun 2007 tentang Pengelolaan
\end{abstract}

PADJADJARAN Journal of Law Volume 6 Number 1 Year 2019 [ISSN 2460-1543] [e-ISSN 2442-9325]

\footnotetext{
Lecturer of Law Study, Faculty of Social and Politic Science, Universitas Sulawesi Barat, Jalan Prof. Dr. Baharuddin Lopa, S.H., Baurung, Banggae Timur, Majene, S.H., M.H. (Universitas Islam Indonesia), Dr. (Universitas Dipenogoro), puteraastomo@unsulbar.ac.id

** Lecturer of Law Study, Faculty of Social and Politic Science, Universitas Sulawesi Barat, Jalan Prof. Dr. Baharuddin Lopa, S.H., Baurung, Banggae Timur, Majene, S.H., M.H. (Universitas Hasanuddin), asrulhukum@gmail.com.
} 
Wilayah Pesisir dan Pulau-Pulau Kecil memberikan kesempatan kepada pemilik modal besar melalui Hak Pengusahaan Perairan Pesisir (HP-3) tetapi substansinya tidak memberikan ruang bagi masyarakat pesisir khususnya nelayan melakukan aktivitas ekonomi di wilayah pesisir. Masyarakat pesisir karena keterbatasan modal dan teknologi tidak mampu bersaing dengan pemilik modal besar akhirnya tingkat kemiskinan nelayan semakin meningkat. Akhirnya UU No. 41 Tahun 1999 tentang Kehutanan dan UU No. 27 Tahun 2007 tentang Pengelolaan Wilayah Pesisir dan Pulau-Pulau Kecil diuji material ke Mahkamah Konstitusi. Metode penelitian yang digunakan dalam penelitian ini adalah penelitian hukum normatif. Hasil penelitiannya adalah bentuk perlindungan hukum terhadap eksistensi kesatuan masyarakat hukum adat dan hak-hak tradisionalnya meliputi: perlindungan terhadap hak ulayat kesatuan masyarakat hukum adat atas status dan pengelolaan hutan adat serta perlindungan terhadap kesatuan masyarakat hukum adat atas pengelolaan wilayah pesisir dan pulau-pulau kecil.

Kata kunci : kesatuan masyarakat hukum adat, perlindungan hukum, putusan.

\section{A. Introduction}

The existence of indigenous law communities in the Republic of Indonesia is recognized and protected in Article 18(B)(2) of the 1945 Constitution. It states that the State recognizes and respects indigenous law communities along with their traditional rights as long as they are still alive and in line with the people development and the principle of the State. Furthermore, Article $28(I)(3)$ of the 1945 Constitution states that the cultural identity and the rights of traditional communities are respected along with the development of the times and civilizations. Therefore, the State forms laws to regulate the indigenous communities. They are, among others, the Law Number 5 of 1960 on Agrarian Principles (Agrarian Principles Law), the Law Number 41 of 1999 on Forestry (Forestry Law), the Law Number 7 of 2004 on Water Resources, the Law Number 31 of 2004 on Fisheries, the Law Number 26 of 2007 on Spatial Planning, the Law Number 27 of 2007 on Management of Coastal Areas and Small Islands (Management of Coastal Areas and Small Islands Law), and the Law Number 1 of 2014 on the Amendment to the Law Number 27 of 2007 on Management of Coastal Areas and Small Islands.

The laws and regulations are contrary to the Article 18(B)(2) of the 1945 Constitution. In other words, they are unconstitutional. First, the status of Indigenous Forests is categorized as State Forest as stipulated in the Forestry Law. This raises a problem. Firstly, the government has the authority to determine indigenous forests as long as the relevant indigenous law communities still exist and their existence is recognized. If the relevant indigenous law communities do not exist anymore during its development, then the indigenous forest 
management rights are returned to the Government. ${ }^{1}$ In fact, the position of the state is very strong in determining the status of indigenous forests. This does not protect the existence of indigenous law communities because even though they are still alive, they cannot own and manage indigenous forests if the state does not recognize them. Secondly, this can damage the values of the indigenous forest because the traditional rights of indigenous law communities are one of the indigenous forest ownership status based on indigenous law. Thirdly, the state prohibits everyone from herding cattle in forest areas that are not designated specifically for this purpose by the competent authority. ${ }^{2}$ Herding cattle (cows, buffaloes, goats, chickens, etc.) in the indigenous forest area is the implementation of traditional rights of the indigenous law. It is done by utilizing indigenous forest areas to herd livestock and put them on the market to sell. This is because the state will not consistently protect the indigenous law communities and its traditional rights if the state prohibits everyone from pasturing their livestock in forest areas. Finally, the Forestry Law trials the materials to the Constitutional Court because it was considered contrary to the 1945 Constitution and issued two decisions which are the Constitutional Court Verdict Number 35/PUU-X/2012 and the Constitutional Court Verdict Number 95/PUU-XII/2014.

Second, the Management of Coastal Areas and Small Islands Law provides opportunities for business persons (capital owners). They are granted Coastal Water Concession Rights (HP-3) where HP-3 is the right to certain parts of coastal waters for business marine and fisheries, as well as other businesses related to the utilization of Coastal Resources and Small Islands, which cover the sea level and the water column up to the seafloor surface at a certain extent. ${ }^{3}$ HP-3 can be given to Indonesian citizens, legal entities established under Indonesian law, or Indigenous Peoples. ${ }^{4}$ The substance of HP-3 has a negative effect, namely the revocation of the rights of coastal communities in accessing resources both at sea level, water bodies, and under the sea floor. HP-3 does not provide space for coastal communities, especially fishermen to carry out economic activities in coastal areas. Coastal communities, due to limited capital and technology, are not able to compete with large capital owners so that the poverty level of fishermen is increasing. Finally, the Management of Coastal Areas and Small Islands Law was trialed materially at the Constitutional Court because it was considered contrary to the 1945 Constitution of the Republic of Indonesia and issued Constitutional Court Verdict Number 3/PUU-VIII/2010.

\footnotetext{
Article 5 of Law Number 41 of 1999 on Forestry (Forestry Law).

Article 50(3)(i) of Forestry Law.

Article 1(18) of Law Number 27 of 2007 on Management of Coastal Areas and Small Islands (Management of Coastal Areas and Small Islands Law).

4 Article 18 of Management of Coastal Areas and Small Islands Law.
} 
Therefore, the problems of the study cover the forms of legal protection are there against the existence of indigenous law communities and their traditional rights in the Constitutional Court Verdict. This paper aims to find out, understand, and analyze the form of legal protection against the existence of indigenous peoples and their traditional rights in the Constitutional Court Verdict.

\section{B. Definition of Indigenous Law Communities}

According to Ter Haar, indigenous law communities are human entities as a whole. They settle in certain regions, have rulers, have tangible or intangible wealth, have members of which each unit experience life in society, in line with nature, and not even one person among the members have the mind or tendency to wish to dissolve the growing bond or leave in the sense of breaking away from that bond forever. ${ }^{5}$

Ter Haar further explained that indigenous law communities are determined by three factors: ${ }^{6}$

1. Territorial Factors

The legal community is formed because of a sense of attachment to the people they occupy. This means that people who occupy a certain area feel bound and feel as one with the community unit with the occupied area. The element that unites these people is the territory/occupied territory. This community has three types as follows:

a. The Hamlet Community (de Dorpgemeenschap) is a community or a group of people in one small area that usually includes a village (local language: padukuhan) with the support of all community leaders and the center of its position in the area. The examples are villages in Java, Bali, Gampong in Aceh

b. Regional Society (de Streekgemeenschap) is the development of several hamlets that form a larger legal community (parent hamlet). For example, the Curia with its Huta in Angkola and Mandailing, Marga has their hamlets in South Sumatera

c. Federation Society or Combined Hamlets (de Dorpenbond) is several adjoining hamlet communities (neighboring) that form an alliance to organize and manage their interests together. For example, some hamlets regulate and manage clean water channels together, form and organize joint justice, and others. The central area of Batak (Central Batakland) is an example of this type.

2. Genealogical factors

Mochamad Adib Zain and Ahmad Siddiq, "Pengakuan Atas Kedudukan Dan Keberadaan Masyarakat Hukum Adat (MHA) Pasca dibentuknya Undang-Undang Nomor 6 Tahun 2014 Tentang Desa", Jurnal Penelitian Hukum, Vol. 2, No. 2, 2015, p. 66.

6 Bushar Muhammad, Asas-asas Hukum Adat Suatu Pengantar, Jakarta: Pradnya Paramita, 1986, p. 30. 
The legal community is formed because the people feel as ones who come from one descendant/race. In the legal society the people who become its components come from one lineage/race, thus their sense of attachment as a legal community unit occurs because of heredity.

3. Mixed Factors

The Legal community is formed because of a mixture of territorial and genealogical factors. The examples are Euri in Nias, Uma in Mentawai, and Nagari in Minangkabau.

\section{Relationship of the Indigenous Law Communities to Indigenous Law}

The term hukum adat (Indigenous law) in Indonesian Language comes from Arabic words, 'Huk'm' and 'Adah'. Huk'm (plural form: Ahkam) means order or provision. For example, in Islamic law (sharia), there are five types of orders (commands) called al-ahkam al-khamsah (the five laws). They are fardh (obligatory), haram (prohibition), mandub or sunnah (recommendation), makruh (reproach) and jaiz, mubah or halal (skill). ${ }^{7}$ Adah or adat means habit. It refers to community behavior that always happens. Therefore, a Indigenous law is a habit law. ${ }^{8}$

According to C. Snouck Hurgronje, indigenous law is a custom that has sanctions (reactions), as long as the custom is a normative habit manifested as behavior that prevails in society without causing sanctions (reactions). ${ }^{9}$ The author considers Hurgronje's opinion distinguishes indigenous and indigenous law in which the latter creates sanctions (punishments) if violated while adat is only in the form of behavior without causing sanctions.

Hurgronje's opinion is the same as Van Vollenhoven's. In which he states that indigenous law is the rules of conduct that apply to indigenous people and foreign Eastern people who on the one hand have sanctions (hence said to be legal) and on the other hand are not codified (hence it is said to be indigenous). ${ }^{10}$ It is different from Ter Haar's opinion which states that indigenous law is the whole rule that is transformed from the decisions of the legal functionaries (in the broad sense) who have authority and have influence and in its enforcement are adhered to wholeheartedly. The holders of power (People's Chief and Meeting) maintain and decide Indigenous law in an eternal process. ${ }^{11}$ This means that the emphasis of Ter Haar's opinion is that indigenous law is a rule that originates from the decisions of traditional leaders as holders of power in indigenous law.

Asaf A.A. Fyzee, Pokok-Pokok Hukum Islam I, translated by Arifin Bey, M.A, Jakarta: Tintamas, 1959, p. 23.

Hilman Hadikusuma, Pengantar IImu Hukum Adat Indonesia, revised edition, Bandung: Mandar Maju, 2014, p. 8.

9 Tolib Setiady, Intisari Hukum Adat Indonesia (Dalam Kajian Kepustakaan), $3^{\text {rd }}$ edition, Bandung: CV. Alfabeta, 2013, p. 8.

10 Ibid., p. 9.

11 Ibid., p. 11. 
Based on indigenous law theory, the indigenous law communities as a communal community makes the law a life guide and rules for the realization of an orderly, safe, peaceful, and harmonious life. Applicable indigenous law creates legal consequences for indigenous people who commit violations.

The indigenous law community begins with the view of life that the individual human is part of the group and they must sacrifice for the survival and welfare of their group. ${ }^{12}$ It can be understood that aspects of indigenous law include the following. ${ }^{13}$

\section{Traditional}

In general, Indigenous law has a traditional pattern, the hereditary meaning from the time of the ancestors to the children and grandchildren is now still valid and maintained by the relevant community.

2. Religion

Indigenous law is generally religious (magical-religious), meaning that the behavior of the law or legal rules is related to trust in the unseen and/or based on the teachings of God Almighty.

3. Togetherness

Indigenous law has a communal style, which means prioritizing shared interests in which personal interests are overwhelmed by mutual interests. "One for all and all for one". Legal relations between one community member and another are based on togetherness, family, help, and cooperation.

4. Concrete and Visual

The style of indigenous law is concrete; meaning clear, real, and tangible. Visual; meaning can be seen, looked, open, not hidden. Therefore, the nature of the relationship of law that applies in indigenous law is "bright and cash", not vague, bright witnessed, known, seen and heard by others, and appears to occur "consent (hand over the receipt)".

5. Open and Simple

The pattern of indigenous law is open, meaning that it can accept the entry of elements that come from outside the origin as long as they do not conflict with the spirit of indigenous law itself. The style and nature are simple; meaning simple, not difficult, not much administration, even mostly unwritten, easy to understand, and implemented based on mutual trust.

6. Can Change and Adjust

Indigenous law can change according to circumstances, time, and place.

7. Not Codified

Most indigenous laws are not written. Although some are recorded in regional scripts, some are even recorded in a non-systematic way. However, they are

12 Paripurna P Sugarda, "Posisi Hukum Adat Dalam Hukum Kontrak Nasional Indonesia", Jurnal Yustisia, Vol. 4, No. 3, 2015, p. 506.

13 Hilman Hadikusuma, op.cit., pp. 33-38. 
only as guidelines and not absolutely necessary, except those that are God's commands. So indigenous law, in general, is not codified like western law (Europe) which is arranged regularly in a book called the law book. Therefore, indigenous law is easy to change and can be adapted to the development of society.

8. Deliberation and Consensus

Indigenous law prioritizes deliberation and consensus in the family, in kinship, and neighboring relations. Both are prioritized to start and end a job as well as being judicial in resolving disputes between one and the other. In resolving disputes, the priority is to settle getting along well and peacefully with deliberation and consensus, by forgiving each other, not hurrying to convey it immediately to the state court. The road to peaceful settlement requires the goodwill of the parties and the existence of a fair and wise spirit of the people entrusted as mediators or enthusiasm from the Indigenous Consultative Assembly.

\section{Existence of the Indigenous Law Communities in Indonesia}

The existence of indigenous law communities in Indonesia can be understood historically in the period leading up to independence, which was marked by the formulation of the 1945 Constitution in the BPUPKI Session May 29, 1945.

Moh. Yamin, in his concept, states that Nagari, Desa, and all indigenous law alliances were renewed in the way of rationalism. The renewal of the times is made as the basic footing of the arrangement. Between the top and the bottom, a central part is formed as a Government to run the Internal Affairs Government, Pangreh Praja. ${ }^{14}$ Moh. Yamin also attached temporary bill of the formulation of the Basic Law that contained Regional Government. It reads the division of the Indonesian region over large and small regions, with the form of the government stipulated by law, by looking at and remembering the basis of consultation in the state government system, and origin rights in a special area. ${ }^{15}$

Soepomo as Chair of the Small Committee for the Designing of the Basic Law in the BPUPKI Session on July 15, 1945 also conveyed his concept. He stated that aside from that, the committee reminded small areas that had the original arrangement, Namely Volksgemeinshaften. It is possible that this word was wrong but what it meant was a small area - small community that has a structure such as in Java, Village; in Minangkabau, Nagari; in Tapanuli, Huta; in Aceh, Kampong. All small regions have a composition of people, this special area, the royal area (zelfbesturendelandschappen) should be respected and its original arrangement

14 Putera Astomo, “Konstruksi Pengawasan Peraturan Desa Adat Setelah Berlakunya Undang-Undang Nomor 6 Tahun 2014 tentang Desa (Studi Awig-Awig Desa Pakraman Di Provinsi Bali)," Disertasi, Fakultas Hukum Universitas Diponegoro, Semarang, 2018, p. 161.

15 Ibid. 
observed. Regarding the region, we agree to a form of unity, thus under the central government, there is no country anymore. There is no airport, but only the area. The form of the area and the form of regional government are stipulated in the law. ${ }^{16}$

According to Moh. Yamin's and Soepomo's concept of thought about indigenous law, community is a community unit that is classified as a small area that inhabits a certain area and has an original arrangement (government structure) based on the right of origin that must be respected. The thoughts of these two figures can be related to the concept of indigenous law communities explained by Ter Haar. The conclusion is that indigenous peoples are human entities as a whole, settled in certain areas (territorial), and have rulers (the structure of government/original arrangement).

On August 18, 1945, a session of the Preparatory Committee for Indonesian Independence passed the Constitution. Explanation of Article 18 of the 1945 Constitution states that Indonesia will not have an area within its environment which is of nature too because the State of Indonesia is an eenheidsstaat. The Indonesian region will be divided into provincial areas and the province will be divided into smaller regions. In areas that are autonomous (streek and locale rechtsgemeenschappen) or mere administrative regions, law will stipulate everything according to the rules. In regions that are autonomous in nature, there will be a regional representative body because the government will be joined on the basis of consultation in the regions. Furthermore, Part II states that there are approximately 250 zelfbesturendelandschappen and volksgemeenschappen. These include villages in Java and Bali, countries in Minangkabau, hamlets and clans in Palembang, and so on. These regions have an original arrangement, and therefore can be considered as special areas. The Republic of Indonesia respects the position of these special regions and all state regulations concerning these regions will remember the rights of the origin of the region. ${ }^{17}$

During the period of 1999-2002, there was a change in the 1945 Constitution. Changes were made once in four stages. The post-amendment to the 1945 Constitution distinguishes between special and special regional government units with arrangements regarding volksgemeenschappen (areas of indigenous law communities) arranged in a separate paragraph. Recognition of the volksgemeenschappen must also be based on certain constitutional requirements. This is certainly different from the 1945 Constitution before the change, which 
generalized zelfbesturendelandschappen and volksgemeenschappen as special regions. $^{18}$

Article 18 of the 1945 Constitution changes and adds verses. It also added some articles namely Article $18 \mathrm{~A}$ and Article 18B. The former regulates the relationship of authority between the central government and provincial, regency, and city governments, or between provinces and districts and cities. The latter regulates special regions, special regions, and indigenous law communities. In particular, Article 18(B)(2) of the 1945 Constitution reads that the State recognizes and respects indigenous law communities along with their traditional rights as long as they are alive and in line with the development of society and the principles of the Unitary State of the Republic of Indonesia. In addition, it is also emphasized in Article $28(I)(3)$ of the 1945 Constitution, which states that cultural identity and the rights of traditional communities are respected in line with the development of the times and civilizations.

According to Yance, in theory, there are four rights of indigenous law communities as follows. ${ }^{19}$

1. The right to control (possess, control) and manage (safeguard, utilize) land and natural resources in their indigenous territories

2. The right to self-regulation in accordance with indigenous law (including indigenous justice) and indigenous rules agreed upon by indigenous peoples

3. The right to take care of themselves based on indigenous management/institutional systems

4. Right to identity, culture, belief system (religion), knowledge system (traditional wisdom), and native language

According to the authors, the elements of the indigenous law communities are as follows:

1. Have the original structure and traditional rights/origin rights. The original arrangement in question is to have a clear area and boundaries, population, and administration. While the traditional rights/origin rights referred to are regulating and managing government affairs that become their own household as well as maintaining living traditions in society and indigenous law that applies in it

2. The existence of indigenous law community units as long as they are alive and in line with community development means that the indigenous law community unit is still actively carrying out all its daily activities. The activities can be varied, range from government management, regulating people's lives,

18 Irfan Nur Rahman, et.al., "Dasar Pertimbangan Yuridis Kedudukan Hukum (Legal Standing) Kesatuan Masyarakat Hukum Adat dalam Proses Pengujian Undang-Undang di Mahkamah Konstitusi", Jurnal Konstitusi, Vol. 8, No. 5, 2011, p. 771.

19 Yance Arizona, "Hak Ulayat : Pendekatan Hak Asasi Manusia dan Konstitusionalisme Indonesia", Jurnal Konstitusi, Vol. 6, No. 2, 2009, p. 105. 
implementing traditions, and enforcing the indigenous law that applies continuously. Their activeness must be in line with the development of people's lives in their territory without leaving the traditions that have become their identities

3. The existence of indigenous law communities as long as they are in accordance with the principles of the Unitary State of the Republic of Indonesia means that they are in a unitary state because the principles of a unitary state include the following.

a. The highest government power is in the hands of the Central Government

b. A unitary state with a decentralized system gives space to hand over authority in the form of governmental affairs to the lowest Government, namely the indigenous law communities. Except government affairs which become Central Government authorities such as: foreign policy, defense, security, justice, national monetary and fiscal policies, and religion. Submission of authority is called autonomy

c. The unitary state recognizes the existence of indigenous law as a living law in the life of the indigenous law communities.

The existence of indigenous law community is strengthened by the Constitutional Court Verdict Number 31/PUU-V/2007, which provides firmness about the existence and criteria of indigenous law communities including:

1. The indigenous law communities can be said to still be alive if de facto contains elements. These include people whose citizens have group feelings, indigenous government, assets or indigenous objects, and indigenous law norms

2. The indigenous law community unit and its traditional rights are in line with the principle of a unitary state. In essence, its existence does not threaten the sovereignty and integrity of the Republic of Indonesia, the substance of legal norms the custom is in line with, and does not conflict with the laws and regulations

3. The indigenous law communities and its traditional rights are in line with the development of the community if their existence has been recognized under the Law (general or sectoral including Perda), the substance of traditional rights is recognized and respected by the relevant members of the indigenous law community as well as the wider community who do not contradict to human rights

D. Forms of Legal Protection against the Existence of the Indigenous Law Communities and its Traditional Rights Judging from the Verdict of the Constitutional Court

1. Legal Protection of Ulayat Rights of the Indigenous Law Communities over the Status of Ownership and Management of Indigenous Forests 
The ulayat rights of indigenous law communities to the status of ownership and management of indigenous forests need to be studied by understanding the theory of ulayat rights first. According to Budi Harsono, ulayat rights are a series of authorities and obligations of indigenous law community that are related to land located within its territory. ${ }^{20}$

Ulayat rights contain two elements. They are the element of belonging, which includes the field of civil law and the element of duty-authority to regulate control, and lead to joint land use which is included in the field of public law. The taskauthority element, including the field of public law, is delegated to the indigenous leaders themselves or together with the traditional elders of the indigenous law communities concerned. ${ }^{21}$

Maria Sumardjono explained the same thing juridically. Ulayat rights is a right that is inherent as a distinctive competency in the form of authority/power to manage and regulate the land and its contents, with the practice of being inside and outside the indigenous law communities. ${ }^{22}$ Therefore, the indigenous law community is the incarnation of all its members who have ulayat rights. ${ }^{23}$

Recognition of the existence of ulayat rights is affirmed in Article 33 Paragraph (3) of the 1945 Constitution, which states that the earth, water, and natural resources contained therein are controlled by the state and used for the greatest prosperity of the people.

According to the author, the important role of the State on earth, water, and natural wealth is not only narrowly interpreted as "mere mastery", but broadly means that it controls it by showing the potential/ability to manage them as well as possible. It is for the sake of the realization of the life of a just and prosperous people while still promoting human values so as not to cause arbitrary actions to the people.

According to Yance Arizona, it is important to involve the community, from beginning to end, in the process of recognizing ulayat rights law of indigenous law communities. This process must provide opportunities for the indigenous and tribal communities to be directly involved and provide oversight, and not just socialization or public hearings. The process of legal recognition in these dynamics requires a strong and solid indigenous law community to oversee the policies,

\footnotetext{
20 Budi Harsono, Hukum Agraria Indonesia, Sejarah Pembentukan UUPA, Isi dan Pelaksanaannya, Jilid I, $9^{\text {th }}$ edition, Jakarta: Djambatan, 2003, p. 179.

21 lbid., p. 250.

22 Maria Sumardjono, Kebijakan Pertanahan antara Regulasi dan Implementasi, Jakarta: Penerbit Kompas, 2007, p. 55.

23 Sahrina Safiuddin, "Hak Ulayat Masyarakat Hukum Adat dan Hak Menguasai Negara di Taman Nasional Rawa AOPA Watumohai", Jurnal Mimbar Hukum, Vol. 30, No. 1, 2018, p. 69.
} 
efforts, and implementation of legal recognition of indigenous law communities' rights to their ulayat rights. ${ }^{24}$

Recognition of ulayat rights in its history other than Article 33(3) of the 1945 Constitution is regulated in the Basic Agrarian Principles Law. It is stipulated in Article 3, which states that the implementation of indigenous rights and similar rights is from indigenous law communities. For as long as they exist, they must be in line with national interests and the state, which is based on national unity and must not conflict with the law and other higher regulations.

One of the ulayat rights of indigenous law community is the status of ownership and management of indigenous forests. The right to an indigenous forest is the right of the indigenous law communities, as guaranteed in the Minister of Agrarian Regulation/Head of the National Land Agency Number 10 of 2016 on Procedures for Determining Communal Rights on the Land of Indigenous Law Communities and Communities in Certain Areas.

Indigenous forests are in fact within the area of ulayat rights. In this area, there are parts of land that are not forest. Instead, they are in the form of grazing fields, graves that function to meet public needs, and individually owned lands to fulfill individual needs. The existence of individual rights is not absolute because they are thinning and thickening at any time. If it gets thinner and disappears, it will eventually become a joint property again. The relationship between individual rights and ulayat rights is flexible. The indigenous forest management rights are in the indigenous law communities. However, if they no longer exist, the rights fall to the government. The authority of ulayat rights is limited to the extent of the contents of individual rights, while the authority of the state is limited as far as the contents and authority of ulayat rights. ${ }^{25}$

Indigenous forests are regulated in the Forestry Law. Ulayat rights of indigenous law communities is related to ownership and management status of indigenous forests as confirmed in Article 67(1) of Forestry Law, which states that the indigenous law community as long as it still exists and is recognized as having the right:

(1) to collect forest products to fulfill the daily needs of the indigenous people concerned;

(2) to carry out forest management activities based on applicable indigenous law and do not conflict with the law; and

(3) to get empowerment in order to improve their welfare.

According to Abdon Nababan, the empirical facts in the field show that the existence of indigenous law communities and their traditional rights actually

24 Yance Arizona, Kuasa dan Hukum: Realitas Pengakuan Hukum terhadap Hak Masyarakat Adat atas Sumber Daya Alam di Indonesia, Jakarta: HuMa dan Epistema Institute, 2010, p. 114.

25 Wahyu Nugroho, "Konstitusionalitas Hak Masyarakat Hukum Adat dalam Mengelola Hutan Adat: Fakta Empiris Legalisasi Perizinan", Jurnal Konstitusi, Vol. 11, No. 1, 2014, pp. 121-122. 
contribute to guarding and protecting the forest. In general, indigenous law communities still respect and practice some principles of local wisdom. They are as follows. ${ }^{26}$

1. They live in harmony with nature by adhering to an ecosystem mechanism where humans are part of an ecosystem that must maintain the balance.

2. The existence of ownership rights and/or joint ownership of the community (communal tenure/property rights) over an area of indigenous forest is still exclusive. It binds all people to protect and secure it from damage.

3. The existence of a traditional knowledge system and institutional structure that provides the ability for the community to solve problems they face jointly in the utilization of forest resources.

4. There is a system of division of labor and enforcement of indigenous law to secure shared resources from overuse both by the community itself and by outsiders;

5. There is a mechanism for equitable distribution of the results of "harvest" of shared natural resources that can reduce social jealousy in the community.

However, some parties argue that the Forestry Law weakens the existence of indigenous law communities and their traditional rights. Therefore, the parties have trialed it to the Constitutional Court. The subject matter in testing the Forestry Law, among others, are as follows.

\section{a. First Problem is the Status of Indigenous Forest as State Forest}

This problem relates to the state's right to control the rights of indigenous peoples to indigenous forests. The concept of state control departs from the theory of state power explained by Van Vollenhoven. The theory explains that the state is the highest organization of the nation that is given the power to regulate everything based on its position over the authority to rule the law. ${ }^{27}$

This study is in the position to view the state in a strong and dominating position especially in determining policies, particularly in determining the status of indigenous forests and their management because of their status as part of the state forest. The state's position is affirmed in Article 5 of Forestry Law, which reads as follows.

(1) Forests based on their status consist of:

a. state forest, and

b. forest rights.

(2) The state forest as referred to in Paragraph (1) letter a, can be in the form of an indigenous forest;

26 Abdon Nababan, "Pengelolaan Hutan Berbasis Masyarakat Adat: Antara Konsep dan Realitas", research paper, Seminar Hutan Tanaman Rakyat, Untuk Apa dan Siapa, Pertemuan Mitra Siemenpuu Foundation, Muara Jambi, 2008, p. 4.

27 Notonagoro, Politik Hukum dan Pembangunan Agraria, Jakarta: Bina Aksara, 1984, p. 99. 
(3) The Government determines the status of the forest as referred to in Paragraph (1) and Paragraph (2), and indigenous forests are stipulated as long as the relevant community is still present and recognized;

(4) If there is no longer any indigenous community in the development, the indigenous forest management rights are returned to the Government.

The Article 5 of Forestry Law shows that two elements of state power stipulate the status of indigenous forests that apply to indigenous law communities. They are, among others, are as follows.

1. The relevant indigenous law community is still present and recognized.

2. The relevant indigenous law community no longer exists in its development, so the indigenous forest management rights are returned to the Government.

This does not protect the existence of indigenous law communities because even if they are still alive, they are not recognized by the state since the communities cannot own and manage indigenous forests.

There is no protection of indigenous law communities over indigenous forests. This causes several Indigenous Peoples, like Alliance of the Archipelago (AMAN), the Kenegerian Kuntu Indigenous Law Communities, and the Kasepuhan Cisitu Indigenous Law Communities, submitting material trial applications for some articles (Article 1(3)(6), Article 5(1), 5(2), 5(3), 5(4), and Article 67(1), 67(2), 67(3) of Forestry Law). At the end of this case examination, the Constitutional Court issued Verdict Number 35/PUU-X/2012.

The Constitutional Court Verdict explains the ownership status of indigenous law communities over indigenous forests. Article 18(B)(2) of the 1945 Constitution essentially asserted that the state recognized and respected indigenous law communities along with their traditional rights as long as they are still alive and in line with the development of society and the principle of the Unitary State of the Republic of Indonesia. This means that one of the traditional rights of the indigenous law communities is ownership and management rights over indigenous forests. Therefore, indigenous forests must be excluded from the status of state forest.

A joint effort between stakeholders, in this case the government and indigenous law communities, is needed for maintaining the preservation of tradition, protecting the rights of indigenous law communities, caring for the culture of the indigenous law communities, and involving indigenous law communities in formulating a policy concerning the unity of the indigenous law communities itself. Apart from being in line with the constitutional mandate, this is also in line with the Constitutional Court Verdict Number 35/PUU-X/2012, which distinguishes indigenous forests and state forests. ${ }^{28}$

28 Esmi Warassih and Sulaiman, "Recognition of Adat Forest and Plantation Concessions in Indonesia", Kanun Jurnal Ilmu Hukum, Vol. 19, No. 2, 2017, pp. 98-110; see also Sulaiman, "Mereposisi Cara Pandang Negara 
Efforts to separate indigenous forests from state forests have produced norms that guarantee legal certainty. They also lead to justice for indigenous law communities in relation to forests as sources of their lives. Through this verdict, the position of the indigenous law communities was raised to a strong position by recognizing their rights clearly and decisively when dealing with a country with weakened rights to control. This concept of thinking is, as stated in the cancellation of Article 1 point 6 of the Forestry Law as long as the word "country", considered contrary to Article 1(3), Article 28(C)(1), Article 28(D)(1), Article 28(G)(1), and Article 33(3) of the 1945 Constitution. ${ }^{29}$

Therefore, the Constitutional Court has annulled Article 1(6), Article 4(3), Article 5(1), 5(2), 5(3) of the Forestry Law because it is contrary to the 1945 Constitution and does not have binding legal force.

\section{b. State actions prohibit anyone from pasturing livestock in forest areas that are not specifically designated}

Herding cattle (cows, buffaloes, goats, chickens, etc.) in the indigenous forest area is the implementation of traditional rights of the indigenous law. It is done by utilizing indigenous forest areas to herd livestock and put them on the market to sell. This is because the state will not consistently protect the indigenous law communities and its traditional rights if the state prohibits everyone from pasturing their livestock in forest areas.

The state ban has caused several petitioner, like Mawardi (Deputy Chair of the Kerapatan Adat Nagari Guguk Malalo, Tanah Datar, West Sumatra Province), Edi Kuswanto (farmer), Rosidi bin Parmo (farmer), Indonesian Forum for the Environment (WALHI), The Nusantara Indigenous Peoples Alliance (AMAN), the Agrarian Reform Consortium (KPA) Foundation, the Palm Oil Monitoring Society (SAWIT WATCH), Indonesia Corruption Watch (ICW), and the SILVAGAMA Foundation filed material tests for Article 50(3)(i) of the Forestry Law. At the end of this case examination, the Constitutional Court issued Verdict Number 95/PUU$\mathrm{XII} / 2014$.

The Constitutional Court Verdict explains everyone should not be prohibited from herding livestock in forest areas for the daily needs of people who live for generations in the forest. Therefore, the Constitutional Court annulled Article 50(3)(i) of Forestry Law because it is contrary to the 1945 Constitution and does not have binding legal force.

terhadap Hukum Adat di Indonesia", Petita Jurnal Kajian Ilmu Hukum dan Syariah, Vol. 2, No. 1, 2017, pp. 3146.

29 Faiq Tobroni, "Menguatkan Hak Masyarakat Adat Atas Hutan Adat (Studi Putusan MK Nomor 35/PUUX/2012)", Jurnal Konstitusi, Vol. 10, No. 3, 2013, p. 476. 


\section{Legal Protection of the Indigenous Law Communities for the Management of Coastal Areas and Small Islands}

There are two important things that underlie the birth of Management of Coastal Areas and Small Islands Law. They are (1) severe coastal damage and (2) the desire to make the coast a subsector to coordinate various sector interests in the coastal region. ${ }^{30}$

According to the author, the Management of Coastal Areas and Small Islands Law does not seem to provide guarantees for the protection of indigenous law communities. This is because they are more pro-business actors who have large capital and sophisticated technology to exploit marine resources in doing their business through the provision of Coastal Water Concession Rights (HP-3). The act of exploitation is sometimes not accompanied by efforts to preserve the environment of the marine ecosystem. It causes damage and does not provide protection to nature in the sea and its surroundings. It also causes the indigenous law communities that work as small fishermen to be unable to manage and utilize marine resources. Therefore, the presence of large capital owners is a barrier for the indigenous law communities to manage coastal areas and small islands as part of their traditional rights.

The Management of Coastal Areas and Small Islands Law was trialed materially to the Constitutional Court by several petitioners. They are People's Coalition for Fisheries Justice (KIARA), Indonesian Human Rights Committee for Social Justice (IHCS), Center for Marine Development Studies and Maritime Civilization (PK2PM), Foundation for Agrarian Reform Consortium (KPA), Indonesian Farmers Union (SPI), Bina Desa Sadajiwa Foundation, Indonesian Legal Aid Foundation (YLBHI), Indonesian Forum for the Environment (WALHI), Indonesian Farmers Alliance (API) related to Article 1(4), 1(7), and 1(18), Article 16(1), Article 23(2) and 23(4). At the end of the examination of this case, the Constitutional Court issues Verdict Number 3/PUU-VIII/2010. The Constitutional Court Verdict explained that the Constitutional Court gave recognition to the indigenous law communities. Among other things, Article 33(3) of the 1945 Constitution determined that the earth, water, and natural resources contained therein were controlled by the state. With the existence of clauses "used for the greatest prosperity of the people", the maximum prosperity of the people is the main measure for the state in determining the management and regulation of the resources contained therein. In addition, state control over the resources must also pay attention to existing rights, both individual rights and collective rights of indigenous law communities (ulayat rights), indigenous communities rights, and other constitutional rights that

\footnotetext{
30 The House of Representatives of The Republic of Indonesia (DPR RI), Proses Pembahasan RUU Pengelolaan Wilayah Pesisir dan Pulau-Pulau Kecil, Book I, Jakarta: Sekjen DPR, 2008, p. 132.
} 
are owned by the community and guaranteed by the constitution. For example, the right of access to pass, the right to a healthy environment, and others.

Therefore, the Constitutional Court has cancelled Article 1(18), Article 16, Article 17, Article 18, Article 19, Article 21, Article 22, Article 23(4) and 23(5), Article 50, Article 51, Article 60(1), Article 71, and Article 75 of the Management of Coastal Areas and Small Islands Law. They contradict the 1945 Constitution.

\section{E. Conclusion}

It can be concluded that the Constitutional Court Verdict contain forms of legal protection on the existence of indigenous law communities and their traditional rights. Firstly, legal protection of the ulayat rights of indigenous law communities to the status of ownership and management of indigenous forests. The right to ownership status of indigenous forests is the ulayat rights of the indigenous law communities. Indigenous forests have values that are still maintained based on the applicable indigenous law in them. Therefore, it is necessary to separate the status of indigenous forests and state forests. The state has an obligation to protect the ulayat rights of indigenous law communities to the status of ownership and management of indigenous forests and to provide supervision of certain parties who may violate the ulayat rights of indigenous law communities, i.e. by illegally exploiting indigenous forests. Secondly, the verdicts cover legal protection for indigenous law communities on the management of coastal areas and small islands. The state has an obligation to protect indigenous law communities over the management of coastal areas and small islands. Coastal communities such as fishermen are given the opportunity to manage and utilize marine resources to meet their daily economic needs. In addition, the state must supervise the large capital and advanced technology of the exploitation of marine resources because there are many exploitation actions that are not completed with efforts of conservation of marine ecosystems. It can cause damage to the sea and does not provide protection on nature, especially the sea and its surroundings.

\section{References}

\section{Books}

Asaf A.A Fyzee, Pokok-Pokok Hukum Islam I, translated by Arifin Bey, M.A. Tintamas, Jakarta, 1959.

Budi Harsono, Hukum Agraria Indonesia, Sejarah Pembentukan UUPA, Isi dan Pelaksanaannya, $9^{\text {th }}$ edition, Djambatan, Jakarta, 2003.

DPR RI, Proses Pembahasan RUU Pengelolaan Wilayah Pesisir dan Pulau-Pulau Kecil, Book I, Sekjen DPR, Jakarta, 2008.

Hilman Hadikusuma, Pengantar IImu Hukum Adat Indonesia, revised edition, Mandar Maju, Bandung, 2014. 
Maria Sumardjono, Kebijakan Pertanahan antara Regulasi dan Implementasi, Kompas, Jakarta, 2007.

Muhammad Bushar, Asas-asas Hukum Adat Suatu Pengantar, Pradnya Paramita, Jakarta, 1986.

ND Fajar, et.al., Dualisme Penelitian Hukum Normatif dan Hukum Empiris, Pustaka Pelajar, Yogyakarta, 2010.

Notonagoro, Politik Hukum dan Pembangunan Agraria, Bina Aksara, Jakarta, 1984.

Tolib Setiady, Intisari Hukum Adat Indonesia (Dalam Kajian Kepustakaan), $3^{\text {rd }}$ edition, CV. Alfabeta, Bandung, 2013.

Yance Arizona, Kuasa dan Hukum: Realitas Pengakuan Hukum terhadap Hak Masyarakat Adat atas Sumber Daya Alam di Indonesia, HuMa dan Epistema Institute, Jakarta, 2010.

\section{Other Documents}

Abdon Nababan, "Pengelolaan Hutan Berbasis Masyarakat Adat: Antara Konsep dan Realitas", research paper, Seminar Hutan Tanaman Rakyat, Untuk Apa dan Siapa, Pertemuan Mitra Siemenpuu Foundation, Muara Jambi, 2009.

Esmi Warassih and Sulaiman, "Recognition of Adat Forest and Plantation Concessions in Indonesia", Kanun Jurnal IImu Hukum, Vol. 19. No. 2, 2017.

Faiq Tobroni, "Menguatkan Hak Masyarakat Adat Atas Hutan Adat (Studi Putusan MK Nomor 35/PUU-X/2012)", Jurnal Konstitusi, Vol. 10. No. 3, 2013.

Mochamad Adib Zain and Ahmad Siddiq, "Pengakuan Atas Kedudukan Dan Keberadaan Masyarakat Hukum Adat (MHA) Pasca dibentuknya UndangUndang Nomor 6 Tahun 2014 Tentang Desa", Jurnal Penelitian Hukum, Vol. 2. No. 2, 2005.

Nur Irfan Rahman, et.al., "Dasar Pertimbangan Yuridis Kedudukan Hukum (Legal Standing) Kesatuan Masyarakat Hukum Adat Dalam Proses Pengujian UndangUndang di Mahkamah Konstitusi", Jurnal Konstitusi, Vol. 8. No. 5, 2005.

P. Paripurna Sugarda, "Posisi Hukum Adat Dalam Hukum Kontrak Nasional Indonesia", Jurnal Yustisia, Vol. 4. No. 3, 2015.

Putera Astomo, "Konstruksi Pengawasan Peraturan Desa Adat Setelah Berlakunya Undang-Undang Nomor 6 Tahun 2014 Tentang Desa (Studi Awig-Awig Desa Pakraman Di Provinsi Bali)", Disertasi, Fakultas Hukum Universitas Diponegoro, 2018.

Sahrina Safiuddin, "Hak Ulayat Masyarakat Hukum Adat Dan Hak Menguasai Negara Di Taman Nasional Rawa AOPA Watumohai", Jurnal Mimbar Hukum, Vol. 30. No. 1, 2015.

Sulaiman, "Mereposisi Cara Pandang Negara terhadap Hukum Adat di Indonesia", Petita Jurnal Kajian Ilmu Hukum dan Syariat, Vol. 2. No. 1, 2015. 
Wahyu Nugroho, "Konstitusionalitas Hak Masyarakat Hukum Adat dalam Mengelola Hutan Adat: Fakta Empiris Legalisasi Perizinan", Jurnal Konstitusi, Vol. 11. No. 1, 2014.

Yance Arizona, "Hak Ulayat : Pendekatan Hak Asasi Manusia dan Konstitusionalisme Indonesia", Jurnal Konstitusi, Vol. 6. No. 2, 2009.

\section{Legal Documents}

The 1945 Constitution of the Republic of Indonesia.

Law Number 5 of 1960 on Agrarian Principles [Undang-Undang Nomor 5 Tahun 1960 tentang Peraturan Dasar Pokok-Pokok Agraria].

Law Number 41 of 1999 on Forestry [Undang-Undang Nomor 41 Tahun 1999 tentang Kehutanan].

Law Number 7 of 2004 on Water Resources [Undang-Undang Nomor 7 Tahun 2004 tentang Pengairan].

Law Number 31 of 2004 on Fishery [Undang-Undang Nomor 31 Tahun 2004 tentang Perikanan].

Law Number 26 of 2007 on Spatial Planning [Undang-Undang Nomor 26 Tahun 2007 tentang Penataan Ruang].

Law Number 27 of 2007 on Management of Coastal Areas and Small Islands [Undang-Undang Nomor 26 Tahun 2007 tentang Pengelolaan Wilayah Pesisir dan Pulau-Pulau Kecil].

Law Number 1 of 2014 on Amandment of Law Number 27 of 2007 on Management of Coastal Areas and Small Islands [Undang-Undang Nomor 1 Tahun 2014 tentang Perubahan atas Undang-Undang Nomor 27 Tahun 2007 tentang Pengelolaan Wilayah Pesisir dan Pulau-Pulau Kecil].

Constitutional Court Verdict Number 31/PUU-V/2007.

Constitutional Court Verdict Number 3/PUU-VIII/2010.

Constitutional Court Verdict Number 35/PUU-X/2012.

Constitutional Court Verdict Number 95/PUU-XII/2014. 